\title{
Erratum I Erratum
}

\section{Erratum k: „Doporučený postup České kardiologické společnosti pro diagnostiku a léčbu chronického srdečního selhání, 2011" [Cor Vasa 2012;54:161-182]}

(Erratum to: "Czech Society of Cardiology guidelines for the diagnosis and treatment of chronic heart failure 2011" [Cor et Vasa 54 (2012) e113-e134])

Jindřich Špinara , Jiří Vítovec ${ }^{b}$, Jaromír Hradec ${ }^{c}$, Ivan Málek ${ }^{d}$, Jaroslav Meluzín ${ }^{b}$, Lenka Špinarováb, Lenka Hoškovád, Markéta Hegarovád, Ondřej Ludkaa, Miloš Táborskýe

a Interní kardiologická klinika, Lékařská fakulta Masarykovy univerzity a Fakultní nemocnice Brno, Brno, Česká republika

b I. interní kardioangiologická klinika, Lékařská fakulta Masarykovy univerzity a Fakultní nemocnice u sv. Anny, Brno, Česká republika

c III. interní klinika, 1. lékařská fakulta Univerzity Karlovy a Všeobecná fakultní nemocnice, Praha, Česká republika

${ }^{a}$ Klinika kardiologie, Institut klinické a experimentální medicíny, Praha, Česká republika

e I. interní klinika - kardiologická, Lékařská fakulta Univerzity Palackého a Fakultní nemocnice Olomouc, Olomouc, Česká republika

Na straně 173 oddílu 6.5 .9 druhého odstavce by třetí věta měla být:

Doporučená úvodní dávka je $2 \times 5$ mg, maximální denní dávka 2× 7,5 mg.

Adresa: Prof. MUDr. Jiří Vítovec, CSc., FESC, I. interní kardioangiologická klinika, Lékařská fakulta Masarykovy univerzity a Fakultní nemocnice u sv. Anny, Pekařská 53, 65691 Brno, e-mail: jiri.vitovec@fnusa.cz

(C) 2012, ČKS. Published by Elsevier Urban and Partner Sp. z o.o. All rights reserved.

DOI: 10.1016/j.crvasa.2012.03.002 